non-protein nitrogenous bodies, provided the patient be eating, and the kidneys not properiy working? And how do the amino-compounds (and allied bodies), absent in health, but present in the urine in these cases get into the urine? They must come in part at least from the blood. And how is their presence in the blood explained, except by an insufficiency of the liver?

Recognising Dr. Mackenzie Wallis as an authority on this matter, I have just looked up his recent article, the Toxæmias of Pregnancy. ${ }^{1}$ I find he says much the same as the writer of The LANcET article. This is what he says: "In toxæmias of pregnancy the results of an analysis of the blood show no striking deviations from those found in normal pregnant women. The blood urea content is usually within the normal limits. . . The same applies to the sugar in the blood. ..." But he says not a word about any other non-protein nitrogenous body. Throughout his article his blood test refers for the most part to the discovery of the urea content. Of course, if the patient is eating and the liver not functioning, one cannot expect as much urea to be formed as would be the case in the normal. But unless one excludes the presence of other non-protein nitrogenous bodies that may possibly be in the blood (and may possibly cause the fits), or has shown they do not occur in greater quantity than in health (Bayliss ${ }^{2}$ ), the categorical statement that in the preeclamptic state there is an absence of a definite nitrogenous retention seems to me unwarranted and misleading. Because, you know, ${ }^{3}$ the occurrence of the toxæmias of pregnancy and of eclampsia, after all, may not be due to the wonderful "toxin or toxins " of which everyone is speaking. In any case, such a statement as that I have referred to coming from The LANCET seemed to me to require clearing up, or qualification. The statement may be perfectly correct. If it is, then I can only suppose that the functions of the liver are limited to the storing of carbohydrate, the formation of bile, and possibly others, but that its supposed urea production is an exaggeration. And I must suppose when an Eck's fistula is made in the $\mathrm{dog}$ and the animal is given meat that the ensuing convulsions are the result either of a depletion of carbohydrate in the liver (as Prof. Harding suggests is the cause of pernicious vomiting ${ }^{4}$ ), or that it is the result of an experimental error, and in any case is to be neglected.

I am, Sir, yours faithfully,

$$
\text { R. H. Paramore, F.R.C.S. Eng. }
$$

Rugby, Sept. 17th, 1921 .

\section{VERONAL AGAINST SEA-SICKNESS.} To the Editor of THE LANCET.

SIR,-Dr. T. Zangger's experience (THE LANCET, Sept. 17th, p. 630) agrees with my own, though, fortunately, mine was not acquired in my own person. In 1912, while acting as surgeon in the Union Castle Co., I had an exceedingly troublesome case of seasickness in a woman who was previously suffering from the vomiting of pregnancy. There were several other doctors on board and one of them ( $\mathrm{I}$ believe Dr. Ashe of Kimberley) advised me to try veronal. I did not carry any in stock but managed to collect enough from passengers to go on with. I had had no previous experience of this drug other than as a sleepingdraught, so was afraid to push it. As long as the patient was under the influence of veronal the vomiting ceased and when it recurred it was checked by a further dose. The patient arrived safely though very weak. A second pregnant woman in a later voyage became sea-sick; I gave her a 10-grain dose on my morning round and by 5 o'clock she was quite cheery. A

1 Journ. of Obstet. and Gyn. of the Brit. Emp., vol. xxviii. No. 1 (New Series), Spring, 1921, j. 11.

Principles of General Physiology, 1920, p. 265 (first two lines) Some Problems of Midwifery, THE LANCET, July 12th, 1913, p. 87. August 13th, 1921 , p. 327 . second attack a few days later was checked permanently by one dose. $\Lambda$ s far as I remember, out of all the cases in which I used the drug (and I used no other) only one failed to respond to a 10-grain dose.

My experience of treating sea-sickness was not nearly as large as I should have expected, as most people seem to prefer to suffer in solitude unless the attack is very severe.

I am, Sir, yours faithfully,

Clevedon, Somerset, Sept. 19th, 1921. R. L. WAson.

TRYPANOSOMIASIS :

A NEW METHOD OF TREATMENT.

To the Editor of THE LANCET.

SIR, - With reference to the paper on this subject read by Dr. C. H. Marshall, senior medical officer to the Uganda Protectorate, at the Royal Society of Tropical Medicine and Hygiene (THE LANCET, June 4th, p. 1185), I am surprised that neither in this paper nor during the subsequent discussion was any mention made of the fact that this method of treatment was suggested as far back as 1907 by Thiroux and d'Aufreville, who wrote ${ }^{1}$ as follows :-

"There is reason to conjecture that sero-therapy will not give results in meningeal trypanosomiasis unless the antitoxin is injected into the spinal canal or cerebral substance, as has been done for tetanus antitoxin."

No statement can be clearer than this. During 1909 a review ${ }^{2}$ under the heading " A Suggestion for 'Treatment," by Dr. Andrew Balfour, goes on to say:-

"In a memorandum headed 'The Treatment of Sleeping Sickness : A Suggestion,' forwarded to the Bureau by Colonel Mathias, R.A.M.C., President of the Sudan Sleeping Sickness Commission, and dated Nor. 17th, 1908, Dr. Andrew Balfour draws attention to the results obtained by Drs. Mackenzie and Martin, in the treatment of cerebrospinal meningitis 'by their method of introducing locally by spinal puncture a highly immune serum which they had obtained from the blood of patients who had recently recovered from the disease or, as in two successful acute cases, who were still running a course. The latter were injected with their own sera taken on the sixth and seventh day of their illness respectively.

"He suggests a similar use of serum-therapy in cases of trypanosomiasis. He mentions some points in which the diseases resemble one another. He asks if in sleeping sickness the cerebro-spinal fluid is a locus minimæ resistentiæ, does it lack trypanocidal substances? He proposes a combined therapy, the trypanosomes being attacked in the blood by some of the more promising of our present drugs, in the cerebro-spinal fluid by the injection of the patient's own serum or the serum from a case improving under treatment, obtained by defibrinating and centrifuging the blood.

"Dr. Balfour's suggestion is well worth attention. As appears more than once in this number many cases have been met with in which trypanosomes persisted in the cerebrospinal fluid when they could no longer be found in the blood or glands. Martin and Lebcuf found in one instance that tartar emetic, while it cleared the blood of parasites, was without effect on those in the cerebro-spinal fluid. If the action on the parasites is direct this might indicate that the drug does not readily permeate the meninges, and hence is never present within them except in a more dilute state than elsewhere in the body. That this may be so is suggested by Nierenstein's observation that arsenic was absent from the cerebro-spinal fluid of an injected donkey on the first day but appeared on the second. If the action of the drug is indirect the want of trypanocidal substance may be due to the poverty of the cerebro-spinal fluid in cellular elements, Balfour suggests."

Dr. Andrew Balfour, therefore, went a step further when he suggested that the blood serum of patients under treatment with some trypanocide should be used for intrathecal injection. It will be observed from these passages that Prof. Halliburton's expression that " he took exception to scientific workers remaining in the clouds and avoiding propositions of practical importance" is by no means accurate; for it is obvious that the resistance of the meninges against permeation by curative agents introduced in the blood stream was prominently borne in mind by the observers

${ }^{1}$ Bulletin of the Sleeping Sickness Bureau, No. 6, 1909, footnote, p. 223 .

Ibid., No. 4, 1909, p. 163. 
of that day. Further than this, Nierenstein's rescarches appear to invalidate Prof. Ialliburton's statement that the cells lining the choroid plexus constitute an absolute barrier preventing arsenic from entering the cerebro-spinal fluid.

It might not be out of place to draw attention to the past literature on this subject, more especially to the period when inquiry into every form of therapeutics in connexion with trypanosomiasis was at the height of its activity. Consequent on important work on sera by Schilling (1905), Klein and Möllers (1906), Mesnil and Brimont ${ }^{3}$ studied this question and an extract from a review of their paper is as follows :-

Action in vitro of the serums on the trypanosomes.The trypanosomes of the last experiment after half-an-hour's contact with active serums showed a vitality as great as that of the control trypanosomes. It was thought possible that the effect of the serums might be evident later. Trypanosomes were therefore put in contact with active serums, inactive serums, and in the citrated water with which they were diluted, in each case at $18^{\circ}$ and $37^{\circ}$. In a great number of trials no microbicidal action was observed; the active serums behaved like the inactive ; in both the trypanosomes kept their vitality longer than those in the citrated water ; it was kept longer still when heated serums were used. The protective power of the serums is therefore not due to trypanolytic action. The two properties, when they exist together, are independent. Nor did the addition of serum from the mouse to supply complement bring about trypanolysis. The agglutinating power of the serums was very inconstant, and never well marked; it exists also in some fresh serums; agglutinative power has no sort of relation to protective power. Anti-lewisi serum is the only one for which agglutination is characteristic, and here Laveran and Mesnil have shown the independence of agglutinating and preventive power.'

Following on the work of. Laveran and Mesnil, Goebel, ${ }^{4}$ among other conclusions, found that-

(1) Human serum digested at $37^{\circ}$ with trypanosomes does not lose its preventive and curative properties. The parasites which have remained in it preserve their infectivity completely.

(2) "Human serum does not show any opsonic or cytotropic property as regards trypanosomes. In any case it does not change the parasites so as to make them an easy prey for leucocytes."

Research undertaken by Levaditi and Mutermilch is described ${ }^{5}$ as follows :-

"The authors mixed trypanosomes from the blood of a mouse with serum from guinea-pigs killed in the course of a third relapse, and added complement. At $38^{\circ}$ the degree of trypanolysis was proportional to the quantity of trypanocidal serum added. With certain quantities microscopical examination showed that all the parasites were immobile and had become round and transparent. It was thought that sterilisation was complete, but when some of these mixtures were injected into mice the animals became infected with trypanosomes and died. The authors suggested that those parasites which had succeeded in multiplying in the blood of the mice had become resistant to the antibodies with which they were in contact in the test-tube : experiment showed that it was so."

From the above it would appear that the blood serum of animals, whether suffering from trypanosomiasis or not, contains little if any trypanolysin, and that trypanosomes kept for some time in contact with such sera do not lose their infectivity; in fact according to later researches, they become in certain cases resistant. The conclusions that Dr. Marshall arrives at and the hopes expressed that "in man prophylaxis and immunisation against trypanosome infection might be so attained "-i.e., by the use of animal serums-are certainly not supported by the researches of many eminent workers, and are also perhaps not without danger.

Regarding complement-fixation, Beck's experiments, like those of previous workers, led to no practical conclusions. He doubts whether complementfixation will ever become of use in the diagnosis of human trypanosomiasis." " As Dr. Marshall appears to have had such promising results, we trust that he will be given ample opportunity for continuing his

${ }^{s}$ Review in Bulletin, S.S.B., No. 6, 1909, p. 220

Bulletin, S.S.B., No. 7,1909 , p. 259

s Ibid. No. 8,1909 , p. 330 work, and if he can bring it to a satisfactory termination he will have achieved remarkable success. I am sure we all wish him the best of luck.

I am, Sir, yours faithfully,

Dar-es-Salaam, July 14th, 1921.

J. O. ShIRCORE.

* * Dr. Shircore's letter makes it clear that intrathecal serum treatment for trypanosomiasis was tried even earlier than was suggested in an annotation on Sept. 10th, p. 573.-ED. L.

\section{NATIONAL PROVIDENT SCHEME.}

To the Editor of THE LANCET.

Sir,-In the National Provident Scheme for Hospital and Additional Medical Services in London, as detailed in your current issue, is there intended to be any differentiation between earned income and income derived from capital? If there is no such differentiation, what is to prevent an individual, with an income of $\$ 250$ derived from invested capital of $\$ 5000$, from becoming a member at an annual subscription of $£ 1$ ? - I am, Sir, yours faithfully,

Plymouth, Sept. 17th, 1921 .

$$
\text { C. HamiltoN Whiteford. }
$$

\section{The Settites.}

\section{WOMEN'S MEDICAL SERVICE FOR INDIA.}

CERTAIN progressive steps are recorded in the annual report for 1920 of the Women's Medical Service for India (W.M.S.I.), incorporated in the report of the National Association for Supplying Female Medical Aid to the Women of India. ${ }^{1}$ A deputation from 16 members of the Service, received by its President Lady Chelmsford in February, 1920, urged, in the interests of the Service, especially with regard to pay and status, that it should be taken over by the Government of India. Lady Chelmsford replied that though the proposal for a Government service was not at present practicable, the question of increased pay ${ }^{2}$ was already under consideration and the desire for a more definite status would be met if possible. The Viceroy was officially approached by the Council in the following September with a view to obtaining for officers of the W.M.S.I. a place in the Warrant of Precedence in India, and meanwhile local governments were asked to accord to officers of the W.M.S.I. gazetted rank and to issue orders that they be treated on all occasions with the consideration paid to gazetted officers. This last request shows that the lack of official recognition in a country where precedence counts for so much has been felt, and for the dignity of the service it is to be hoped that the response of the Viceroy has been favourable. The United Provinces, alone of the Provinces, had replied when the report was issued and their answer was immediately to bestow gazetted rank on all officers of the W.M.S.I. Meanwhile, the service has altered its internal nomenclature more in accordance with the traditions of a government service, doubtless in hopeful anticipation of a change in the official attitude. Dr. M. I. Balfour, one of the joint secretaries of the service, is now its chief medical officer. The assistants to the surgeonsgeneral or inspectors-general are now to be known as senior medical officers, and those engaged in hospital duties are graded as executive medical officers of the first, second, third, and fourth grades. The bestowal of certain executive powers on the chief medical officer is under consideration.

\section{ROYAL NAVAL MEDICAL SERVICE.}

Surg. Comdrs.-G. D. Walsh to Defiance; C. H. Dawe to President, addl., for four months' hospital course; and F. H. Holl to Renown. Surg. Lieut.-Comdrs. C. F. O. Sankey to Harebell; and W. F. Beattie to Ceres. Surg. Lieut. J. F. Haynes to Woodlark.

Calcutta: Superintendent Government Printing, India. 1921. ${ }^{2}$ The scale of pay recorded in our Students ${ }^{*}$ Number (August 27 th) is the recently revised scale. 